\title{
Chlamydia trachomatis viability testing
}

Citation for published version (APA):

Janssen, K. J. H. (2019). Chlamydia trachomatis viability testing: the next piece of the puzzle in chlamydia control. [Doctoral Thesis, Maastricht University]. Maastricht University. https://doi.org/10.26481/dis.20191106kj

Document status and date:

Published: 01/01/2019

DOI:

10.26481/dis.20191106kj

Document Version:

Publisher's PDF, also known as Version of record

\section{Please check the document version of this publication:}

- A submitted manuscript is the version of the article upon submission and before peer-review. There can be important differences between the submitted version and the official published version of record.

People interested in the research are advised to contact the author for the final version of the publication, or visit the DOI to the publisher's website.

- The final author version and the galley proof are versions of the publication after peer review.

- The final published version features the final layout of the paper including the volume, issue and page numbers.

Link to publication

\footnotetext{
General rights rights.

- You may freely distribute the URL identifying the publication in the public portal. please follow below link for the End User Agreement:

www.umlib.nl/taverne-license

Take down policy

If you believe that this document breaches copyright please contact us at:

repository@maastrichtuniversity.nl

providing details and we will investigate your claim.
}

Copyright and moral rights for the publications made accessible in the public portal are retained by the authors and/or other copyright owners and it is a condition of accessing publications that users recognise and abide by the legal requirements associated with these

- Users may download and print one copy of any publication from the public portal for the purpose of private study or research.

- You may not further distribute the material or use it for any profit-making activity or commercial gain

If the publication is distributed under the terms of Article $25 \mathrm{fa}$ of the Dutch Copyright Act, indicated by the "Taverne" license above, 
Summary

Samenvatting 


\section{Summary}

The studies described in this thesis focused on the development, validation, and clinical application of methods to assess Chlamydia trachomatis (CT) viability.

Chapter 1 provides a general introduction on CT epidemiology, biology, diagnosis and treatment.

\section{Chapter 2: CT methods to assess the clinical diagnostic impact of NAAT results}

The advent of the highly sensitive and specific nucleic acid amplification test (NAAT) revolutionized the field of sexually transmitted infection (STI) diagnostics. However, tests in routine use do not distinguish between viable organisms that can cause clinically relevant disease and non-viable molecular remnants. Therefore, the clinical and public health implications of a positive NAAT result can be unclear. This chapter provides an overview of the strengths and limitations of three currently available methods to determine CT viability and thus the clinical relevance of a positive test result, namely traditional culture, viabilityPCR (V-PCR), and detection of messenger-RNA. Depending on the underlying research question, all three discussed techniques have their merits when testing for viability. However, mRNA methods show the most promise in determining the presence of a true infection, in case the $\mathrm{CT}$ reticulate body can be specifically detected.

\section{Chapter 3: Viability-PCR shows that NAAT detects a high proportion of DNA from non-viable CT}

The aim of this study was to technically validate and implement viability-PCR (V-PCR) for the assessment of CT viability in clinical samples. By using V-PCR we assessed CT viability in predefined ratios of frash and heat-killed CT cultures. Furthermore, we applied V-PCR to vaginal swabs of $50 \mathrm{CT}$ positive patients (diagnosed by NAAT) which were collected at our outpatient STD clinics before treatment. V-PCR showed to be a fast and easy method to assess CT viability in clinical samples, without the need of traditional challenging cell culture methods. Furthermore, V-PCR results of clinical samples have indicated that a substantial amount of the amplified CT DNA originated from non-viable cells.

\section{Chapter 4: CT messenger-RNA as a marker for active infection}

Detection of messenger-RNA (mRNA) molecules has been utilized as a marker for bacterial viability, as mRNA molecules are generally short-lived (half-life of several minutes or hours). Furthermore, previous research demonstrated that CT genes are differentially expressed during the course of the CT developmental cycle. By using a reverse transcriptase real-time PCR (RT-qPCR) method, targeting late stage genes involved in the differentiation of reticulate body (RB) to elementary body forms (EB), we demonstrated that the half-life time of both 
the omcB and hctA gene transcripts were relatively short. Furthermore, relative gene expression analysis showed that both genes were promising as a potential marker for (recent) RB activity, thus may represent active CT intracellular infection. Future studies are warranted to evaluate the time to clearance of mRNA molecules in patients.

\section{Chapter 5: Assessment of rectal CT viable load in women}

In recent years, studies have demonstrated frequent rectal CT detection in women, irrespective of reported anal sex or rectal symptoms. However, the clinical relevance and public health implication of rectal CT detection in women remains under debate. By using $\mathrm{V}$ PCR we evaluated CT viability in rectal swabs $(n=53)$ to provide more insight into the relevance of standard routine NAAT positive results. We found no statistically significant difference $(p=0.73$ ) between the mean rectal viable CT load in women with an indication for rectal testing and without, suggesting similar clinical impact among both groups. Overall, the detection of viable rectal $C T$ in this study indicates that rectal $C T$ in some women might represent a currently ongoing infection rather than just the presence of remnant DNA from dead bacteria or only contamination from an active vaginal infection.

\section{Chapter 6: Determinants associated with viable vaginal or rectal CT load}

For various STIs (e.g. Neisseria gonorrhoeae) it has been demonstrated that organism load is associated with development of clinical complications and transmission potential. For CT, however, the association between organism load and the clinical course of disease (i.e., clinical presentation and risk to develop pathogen-related complications over time) are still unclear. By using V-PCR, this study for the first time determined the viable CT load in a large group ( $n=534$ ) of STI clinic female patients (FemCure). We observed that CT diagnosed women may have higher viable vaginal CT loads when reporting vaginal symptoms or when having a concurrent rectal CT. Furthermore, having a concurrent rectal CT was also independently associated with both viable vaginal load and altered vaginal discharge. The biological mechanisms and potential clinical implications of these findings warrant further study.

\section{Chapter 7: Spontaneous clearance of CT accounting for bacterial viability}

Spontaneous clearance of CT infections can occur between diagnosis and treatment. Despite the high prevalence of rectal CT infections in women, studies on rectal clearance are scarce. Assessment of CT viability as well as evaluating both the vaginal and the rectal site is vital to shed light on the current knowledge gaps regarding spontaneous clearance in women. We assessed the proportion of women $(n=560)$ who tested NAAT negative (indicating absence of CT-DNA) or V-PCR negative (indicating an absence of viable CT) upon return to the clinic for treatment. We found that vaginal CT diagnosed women who were also diagnosed with rectal CT or were rectally untested, only a small proportion showed clearance upon 
treatment (by both NAAT and V-PCR testing). Moreover, most of these women commonly had viable CT at both anatomic sites. Single site infected women showed higher clearance proportions. These findings might have diagnostic and therapeutic implications for women screened for CT.

\section{Chapter 8: General discussion}

There are overall two main aspects regarding CT viability. First, it is unknown whether the detected CT are viable or dead. Second, similar to culture-based diagnostics, it is unclear whether CT detection represents a true infection or not. To address these main aspects, studies in this thesis focused on the development, validation, and clinical and public health application of CT viability testing methods.

Regarding the technical and clinical validation, we demonstrated that both V-PCR and CT mRNA detection methods can effectively distinguish between viable and dead organisms. However, for the detection of a true intracellular infection, mRNA might be the most promising method, assuming that RB can be specifically detected.

Regarding the clinical and public health application of CT viability testing, we found that in about half of rectal CT NAAT diagnosed women viable CT could be detected. Although the clinical and public health relevance of rectal CT in women is still unclear, untreated or suboptimal treated rectal CT might pose a potential reservoir for ongoing transmission and subsequent development of genital- and extra-genital disease related complications.

Several potential sources of rectal CT in women are discussed, including contamination, autoinoculation, and colonization of the Gl tract via oral ingestion. Neither of these transmission routes can be confirmed nor excluded in our current research. However, results suggested that autoinoculation of the rectal site by CT infected vaginal secretions might play an important role in sustaining the high prevalence of rectal CT in women. Future studies are warranted to fully understand the impact (clinical and public health relevance) and transmission routes of rectal CT in women.

Altogether, with the introduction of mRNA detection or V-PCR, sensitive methods have become available that can be implemented in high-throughput routine diagnostics in the near future, further enhancing our ability to optimize CT control. 


\section{Samenvatting}

Dit proefschrift beschrijft verschillende onderzoeken die zich richten op de ontwikkeling, validatie en uiteindelijk het toepassen van testen die de levensvatbaarheid van Chlamydia trachomatis (CT) kunnen bepalen.

Hoofdstuk 1 geeft een algemene inleiding over de epidemiologie, biologie, diagnose en behandeling van $\mathrm{CT}$.

\section{Hoofdstuk 2: Methoden om de levensvatbaarheid van CT te bepalen}

De introductie van de zeer gevoelige en specifieke PCR gebaseerde 'nucleic acid amplification test' (NAAT) zorgde voor een revolutie op het diagnostisch gebied van seksueel overdraagbare aandoeningen (SOA). Deze gevoelige testen maken echter geen onderscheid tussen levensvatbare organismen welke klinisch relevant zijn en niet levensvatbare moleculaire resten (genetisch materiaal van CT). Dit hoofdstuk geeft een overzicht van de voor- en nadelen van drie beschikbare methoden om de levensvatbaarheid van CT te bepalen en daarmee de klinische relevantie. De levensvatbaarheid van CT kan getest worden met bijvoorbeeld traditionele celkweek methode, viability-PCR (V-PCR) en detectie van messenger-RNA (mRNA). Afhankelijk van de onderliggende onderzoeksvraag hebben deze technieken hun eigen voordelen bij het testen op levensvatbaarheid. Echter, mRNA detectie is het meest belovend voor het detecteren van een intracellulaire infectie, mits er een van de intracellulaire stadia van de CT-bacterie - de reticulate body (RB) - specifiek kan worden gedetecteerd.

\section{Hoofdstuk 3: De validatie van de V-PCR methode voor het aantonen van levensvatbare CT}

Het doel van deze studie was om de $\mathrm{V}$-PCR methode te valideren en te implementeren voor de detectie van levensvatbare CT in klinische samples. Middels V-PCR hebben we bepaald hoeveel levende $\mathrm{CT}$ aanwezig was in vooraf gedefinieerde verhoudingen van vers gekweekte en met hitte behandelde CT-kweken. Verder hebben we V-PCR toegepast op vaginale samples van 50 CT NAAT positieve vrouwen die vóór de behandeling samples verzamelden in onze SOA-poli. V-PCR is een snelle en gemakkelijke methode om de levensvatbaarheid van $\mathrm{CT}$ in klinische samples te beoordelen, zonder gebruik te hoeven maken van de traditionele celkweekmethoden. Verder hebben aangetoond dat een groot gedeelte van het DNA in NAAT positieve samples bestaat uit vrij DNA en DNA van dode CT.

\section{Hoofdstuk 4: Aantonen van CT messenger-RNA als marker voor actieve infectie}

Detectie van messenger-RNA (mRNA) is al vaker toegepast als een bio-marker voor het aantonen van levende bacteriën, omdat mRNA-moleculen van dode bacteriën over het algemeen maar een korte levensduur hebben (halfwaardetijd van enkele minuten of uren). 
Verder heeft eerder onderzoek aangetoond dat de verschillende CT genen specifiek tot expressie worden gebracht tijdens de verschillende fasen van de CT levenscyclus. Door gebruik te maken van een real-time reverse transcriptase PCR methode (RT-qPCR) hebben we aangetoond dat de halfwaardetijd van zowel het omcB en hctA-gen relatief kort waren. Omdat deze genen specifiek tot expressie komen tijden de differentiatie van RB naar EB hebben we deze genen ok gebruikt als target en gevolgd tijdens de levenscyclus. Relatieve genexpressie analyse heeft laten zien dat beide genen veelbelovend waren als potentiële marker voor (recente) RB-activiteit, en dus een actieve intracellulaire CT infectie kunnen aantonen. Toekomstige studies zijn nodig om de detectie van mRNA in klinische samples te testen.

\section{Hoofdstuk 5: Levensvatbare anale CT load in vrouwen}

Naast de genitale infecties, komt anale CT ook vaak voor bij vrouwen, ongeacht gerapporteerde anale seks of symptomen. De klinische relevantie en gevolgen voor de verdere transmissie van anale $\mathrm{CT}$ bij vrouwen zijn echter nog niet bekend. Om meer inzicht te krijgen in de klinische relevantie van anale CT bij vrouwen hebben we met V-PCR de levensvatbaarheid van $C T$ in anale samples $(n=53)$ onderzocht. Er was geen statistisch significant verschil $(p=0.73)$ tussen de gemiddelde levende CT load bij vrouwen met een indicatie voor anaal testen en zonder. Dit suggereert een gelijke klinische impact tussen beide groepen. Verder suggereert de detectie van levende CT in anale samples bij vrouwen dat deze anale CT zich potentieel verder kan verspreiden.

\section{Hoofdstuk 6: Determinanten geassocieerd met levensvatbare vaginale of rectale CT load}

Voor verschillende soa's (bv. Neisseria gonorrhoeae) is aangetoond dat de load is geassocieerd met de ontwikkeling van klinische complicaties en de potentie tot verdere verspreiding. Voor CT is dit verband echter nog steeds onduidelijk. Middels V-PCR hebben we in deze studie onderzocht welke determinanten (bv. symptomen en seksueel gedrag) geassocieerd zijn met het aantal levende bacteriën in vaginale en anale samples van vrouwelijke patiënten $(n=534)$ (FemCure). Deze studie heeft laten zien dat wanneer vrouwen vaginale symptomen of een gelijktijdige rectale $\mathrm{CT}$ hebben. Bovendien was het hebben van een gelijktijdige rectale $\mathrm{CT}$ ook onafhankelijk geassocieerd met zowel het aantal levende CT in vaginale samples als ook het hebben van een veranderde vaginale afscheiding. De achterliggende biologische mechanismen (transmissie routes) en mogelijke klinische impact van deze bevindingen zullen verder uitgezocht moeten worden in toekomstige studies.

\section{Hoofdstuk 7: Spontane klaring van CT}

Spontane klaring van CT-infecties kan optreden tussen het moment van de initiële diagnose en de opvolgende behandeling. Ondanks de hoge prevalentie van rectale CT bij vrouwen zijn 
er nog maar weinig studies over rectale klaring. Beoordeling van de levensvatbaarheid van CT en evaluatie van zowel de vaginale als de rectale locatie is essentieel om licht te werpen op de huidige kennishiaten met betrekking tot spontane klaring bij vrouwen. We hebben het aandeel vrouwen $(n=560)$ dat NAAT-negatief getest (wat duidt op afwezigheid van CT-DNA) of V-PCR negatief (wat wijst op een afwezigheid van levende CT) onderzocht op het moment vóór behandeling. Deze studie heeft laten zien dat van de vrouwen met zowel een vaginale als anale CT diagnose slechts een klein deel de CT klaarden (bevestigd met zowel NAAT- als $\mathrm{V}$-PCR). Bovendien hadden de meeste van deze vrouwen vaak levensvatbare CT op beide anatomische locaties. Vrouwen met een geïsoleerde vaginale CT vertoonden meer klaring. Deze bevindingen kunnen diagnostische en therapeutische implicaties hebben voor vrouwen die worden gescreend op CT.

\section{Hoofdstuk 8: Algemene discussie}

Er zijn twee belangrijke aspecten met betrekking tot de moleculaire detectie van CT. Ten eerste is het onbekend of de gedetecteerde CT levensvatbaar of dood is. Ten tweede is het, net als op kweek gebaseerde diagnostiek, onduidelijk of de gedetecteerde CT een aanwijzing is voor een echte infectie. Om deze aspecten te onderzoeken, richtten de studies in dit proefschrift zich op de ontwikkeling, validatie en uiteindelijk het toepassen van testen die de levensvatbaarheid van CT kunnen bepalen.

Bij de technische en klinische validatie hebben we aangetoond dat zowel V-PCR als mRNA detectie goed onderscheid kunnen maken tussen levensvatbare en dode organismen. Voor de detectie van een intracellulaire infectie is mRNA echter de meest veelbelovende methode (ervan uitgaande dat men specifiek de RB kan aantonen).

Het toepassen van deze testen heeft laten zien dat bij ongeveer de helft van de vrouwen met een rectale CT levensvatbare CT kon worden gedetecteerd. Hoewel de gevolgen van rectale CT bij vrouwen nog steeds onduidelijk is, kan een onbehandelde of suboptimaal behandelde rectale CT een mogelijke bron zijn voor de verdere transmissie en mogelijk het ontwikkelen van genitale en extra-genitale complicaties.

Verschillende mogelijke verklaringen van rectale CT bij vrouwen worden besproken, waaronder contaminatie, auto-inoculatie en kolonisatie van het maagdarmkanaal via orale besmetting. We hebben geen van deze mogelijke verklaringen kunnen bevestigen noch kunnen uitsluiten in ons huidige onderzoek. De resultaten in dit proefschrift suggereren echter dat auto inoculatie van het rectum met besmette vaginale afscheiding een belangrijke rol zou kunnen spelen in de hoge prevalentie van rectale CT bij vrouwen. Toekomstige studies zijn nodig om de relevantie en mogelijke transmissieroutes van rectale CT bij vrouwen beter te begrijpen.

Met de detectie van mRNA en de V-PCR test hebben we nieuwe gevoelige methoden ontwikkeld die in de nabije toekomst geïmplementeerd kunnen worden in de routine 
diagnostiek van $\mathrm{CT}$. Implementatie van deze nieuwe testen kan mogelijk bijdragen aan het optimaliseren van het huidige beleid rondom de SOA bestrijding. 
